\title{
WHAT DOES IT TAKE TO BE A TRANSLATOR? : MACAO (CHINA) CASE STUDY
}

\author{
Maria de Lurdes Nogueira Escaleira* \\ Macao Polytechnic Institute
}

\begin{abstract}
This article aims to reflect on the teaching and the learning of translation between Portuguese and Chinese languages, in Macao, and the Macao Polytechnic Institute's role in the training of translators, since $1991^{1}$ to 2004 . Since the arrival of the Portuguese, more than four centuries ago, translation is deemed an essential condition for the functioning of institutions and people's social life. Intercultural and interlinguistic contacts between the Portuguese and Chinese languages, today official languages, have compelled to translation efforts and the training of translators has been an area of primordial research. Over one century of experience in teaching translation, it is critical to analyze the translation labor market from the perspective of the professionals themselves, allowing to identify its characteristics and to figure out the future prospects; such analysis is essential for the curriculum design of translation training programs in line with the translators needs. Before the research we made the following assumptions: (1) the number of translators available in the market is insufficient but, every year, more graduates come to the market; (2) the local market is seeking translators and interpreters who are able to translate any document in any field, in both directions; (3) Macao Public Administration is the largest employer of Chinese-Portuguese translators and also the preferred place to work as a translator; (4) there is a significant number of translators that opt for another career, such as law or assume other duties not related with their
\end{abstract}

* Master degree at Macao University, China; PhD at Oporto University, Portugal. Currently is Associated Professor at Macao Polytechnic Institute, Macao Special Administrative Region, People's Republic of China. Macao, China. E-mail: salselas@hotmail.com

${ }^{1}$ The public higher education in Macao was created in 1991. 
studies. The main focus of this research is the vision of the translation professionals, since it aimed to identify the aspects considered by the translators themselves as the most relevant, and which must be taken into account by the higher education institutions in the translation curriculum design.

Keywords: Translation. Translators. Teaching and learning. Labor market of translation.

\section{O QUE É PRECISO PARA SER TRADUTOR?: ESTUDO DE CASO - MACAU (CHINA)}

Resumo: O presente artigo tem com objectivo reflectir sobre o ensino e a aprendizagem da tradução entre as línguas portuguesa e chinesa, em Macau, e o papel que o Instituto Politécnico de Macau tem desempenhado na formação de tradutores, desde $1991^{2}$ a 2004.

Desde a chegada dos Portugueses, há mais de quatro séculos, a tradução tem sido uma condição essencial para o funcionamento das instituições e da vida social. Os contactos interculturais e interlinguísticos entre os falantes destas duas línguas, actualmente línguas oficiais, obriga a um esforço de tradução, daí que, o ensino desta área de conhecimento seja um importante aspecto a ter em conta pelos investigadores. Com mais de um século de experiência no ensino da tradução, é essencial analisar o mercado da tradução a partir da prespectiva dos próprios profissionais, permitindo identificar as suas características e planear o futuro; esta análise é fundamental para a elaboração de currículos e programas de formação de tradutores, tendo em conta as necessidades dos tradutores.

Partimos para este estudo com as seguintes hipóteses de investigação: (1) o número de tradutores disponíveis no mercado é insuficiente mas, todos os anos, chegam novos licenciados ao mercado; (2) o mercado local procura tradutores e intérpretes com capacidade para traduzir qualquer tipo de texto, de qualquer área do conhecimento, e em ambos os sentidos; (3) a Administração Pública de Macau é o maior empregador de tradutores de chinês-porguguês e, também, o local de trabalho preferido pelos tradutores; (4) existe um número significativo de tradutores que envereda por outra carreira, como por exemplo, advocacia, ou desempenha outras funções não relacionadas com a sua área de estudos.

Nesta investigação, dá-se um especial ênfoque à visão dos profissionais da tradução, visto que se pretende identificar os aspectos considerados pelos próprios tradutores como sendo os mais relevantes e que devem

${ }^{2}$ O ensino superior em Macau foi criado em 1991. 
ser tomados em conta pelas instituições de ensino superior no design dos curricullum.

Palavras-chave: Tradução. Tradutor. Ensinar e aprender. Mercado de trabalho da tradução.

\section{Introduction $^{3}$}

The establishment, for more than four centuries, of the Portuguese in Macao has given rise to a long and unique history of coexistence of two languages (Chinese/Portuguese) that still persist after December 1999. Indeed, the Macao Special Administrative Region Basic Law states the Portuguese language as one of the officials' languages, for a period of 50 years from the date of the handover ${ }^{4}$.

Despite the official status of both languages, actually they have never been on equal terms. Since the establishment of the Portuguese in Macao, Portuguese was the official language of the Territory; yet, being the language mainly used in government and in the public administration until December 1999, it was always been a minority language, with the majority of Macao's population speaking Cantonese (a Chinese dialect).

On the other hand, only in 1991, the Chinese language (Mandarin/Putonghua) was recognized by law (Decree-Law $455 / 91$ ) as an official language and it has been increasingly used by governmental institutions, private organizations and by people in general.

\footnotetext{
${ }^{3}$ This article is part of the research "Translation Teaching in Macao Polytechnic Institute: from the curricula to market needs", developed during the $\mathrm{PhD}$ program at the University of Porto and published under the title A Tradução em Macau: dos curricula propostos à realidade de mercado (Escaleira, M. Lurdes (2012), Macau: Edições Delta).

4 The handover, the transfer of sovereignty over Macau, took place in Dec 20th 1999 ; in its preparation it was decided that the Portuguese Language would remain an official language after the handover.
} 
Taking into account all those factors, we realize the importance of the duo Portuguese/Chinese ${ }^{5}$ in the contacts between Macao, China and the Portuguese-speaking countries, especially Brazil, Angola and Mozambique.

Nowadays, the need of Portuguese-Chinese translators is bigger as a result of China's strong investment in this group of countries, the plans for further developments, and the strengthening of ties between these two worlds. It is an important issue that must be included in the political agenda and, also, must result in relevant research projects.

The key to solve the situation is training translators who can be successful in their career in providing quality services to the market agents. To achieve these objectives, education institutions and the market agents have to closely cooperate, then the academia ${ }^{6}$ must identify and understand market needs in order to train people with the silks needed to a successful integration (within their field of study) in the labor market.

The market agents can give an accurate answer to a whole range of issues related to the training of translators. To address these issues, we conducted a survey to Macao translators trained in the Macao Polytechnic Institute, along with some interviews to translators, teachers, market agents and policy makers. In our study, the questions concerned the following aspects: (1) current situation of the translation labor market; (2) area(s) in need of translation; (3) impact of the intensification of political, economic and cultural relations between the People's Republic of China, Macau, Portugal and the Portuguese-speaking countries; (4) career opportunities for recent or future graduates; (5) forecasts for the next five years.

Despite referring to a limited universe (local and locally trained translators), the analysis of the survey data suggests a set of

\footnotetext{
${ }^{5}$ Cantonese - dialect spoken in Macao, Hong and Guangdong Province - and Mandarin - China's official language.

${ }^{6} \mathrm{We}$ understand that the success of the schools is related with the employment rate of their graduates in their area of studies.
} 
indications to follow in curricula design, teaching materials and strategies, so that the education system can meet the students and translation market agents' expectations.

\section{Context}

The teaching of translation in Macao, with more than a century of history, emerged from a government initiative with respect to the training of translators and interpreters, in order to solve the communication problems with a majority of Chinese speaking population. In 1885, the Repartição do Expediente Sínico was created, by Decree Law, with the objectives to train translators/ interpreters for the Portuguese diplomatic delegations in Beijing, Guangdong and Shanghai and to Macao public administration. Some years later, in 1905, the first school for training of translators and interpreters of Portuguese-Chinese and for Chinese language studies was settled (Escola Técnica), once again under the scope of a public service (Direcção dos Assuntos Chineses). Since that date until 1992, several changes were made in the curricula, mainly to adapt it to the real needs and expectations of students and employers and, especially, to attract students. As a matter of fact, one of the main problems was the lack of students and the government provided incentives and career benefits ${ }^{7}$, to overcome this lack of interest in the translation profession.

The training provided by the Escola Técnica was mainly a practical one and did not confer an academic degree. After the establishment of modern higher education in Macao, in 1992, the Escola Técnica was integrated into the Macao Polytechnic Institute. Initially, the Polytechnic mission was to raise the qualification of existing translators/interpreters, and in a second

\footnotetext{
${ }^{7}$ Public Administration is the main employer and the one offering the best conditions in terms of remuneration, social benefits and career development, in particular for providing opportunities for on-the-job training.
} 
phase, efforts were made in order to design a new curricula for conferring academic degrees.

The situation was peculiar, as we assist to a higher demand for translation work that becomes more acute in the transition period, due to the legal requirement for providing official documents, especially the Law, in both official languages (Portuguese and Chinese). Moreover, the political compromise, assumed by the Portuguese government in the Joint Sino-Portuguese Declaration ${ }^{8}$ in 1987, of localization of Macao's civil service resulted in a considerable number of translators shifting to other roles. In addition, with the creation of the Bachelor Degree in Law at the Macao University, a significant number of translators "gave up" their careers as translator to focus on advocacy.

In recent years, after 2003, the political and economic decision of China of investment in the Portuguese Speaking Countries and the role of Macao as a Platform, led to a greater demand for translation professionals for those languages.

All those factors, stressed the urgent need to train translators to replace those who left the career and also to meet the greater demand of translation and interpretation works. In this scenario, the Macao Polytechnic Institute assumed a proactive attitude, developing partnerships programs with higher education institutions in Mainland China and Portugal and, specially, getting authorization from the PRC's government to recruit students in Mainland China9.

${ }^{8}$ In the Joint Sino-Portuguese Declaration, in 1987, regarding the transfer of sovereignty, Lisbon and Beijing agreed on the localization of Macao's civil service, the status of Chinese as an official language, and the localization of the law.

${ }^{9}$ Although our studies reflects only the situation of Macao translators it's important to note the exchange programs implemented by Macao Polytechnic Institute with the Leiria Polytechnic Institute and the Beijing Language and Culture University; University of Peking, among others (see www.ipm.edu.mo). 


\section{Portuguese/Chinese Translation Work Market}

Globalization is taking place at all levels of society and causes an increase in the quantity and diversity of the demand of linguistic mediation services. Indeed, the removal of barriers between domestic and international markets, and the consequent increasing levels of competitiveness, makes the business agents aware that, to win the battle of competition, they need to communicate with costumers and buyers in their own language.

At the same time, the information age has led to an overall increase in the demand and distribution of information, generating an increased demand for translation of all kinds of media.

Hope and fear in automated translation is over and if we previously thought that technological advances would "steal" jobs from translators, we have witnessed that "[t]he exponential growth of this habitat that has been brought about by a rapid increase of internationalization patterns, is causing an increasing demand for professional pathfinders, both in linguistic and in cultural terms" (Austermühl, 1998:449).

Globalization, advances in telecommunications and the growth of trade relations and cultural exchange were reflected in Macao, a small special administrative region of China, with an open economy based on gambling-related tourism, hosting of international events, such as conferences, international sporting and cultural activities, participation in international organizations, etc.

In this context, translation plays a crucial role in Macao's economic development and cultural exchange; regarding the Portuguese/Chinese translation services market, in a broad sense, it includes all public and private organizations that establish cultural, political and economic contacts between Portuguese-speaking countries and China ${ }^{10}$. This market is growing as contacts between

${ }^{10}$ The Portuguese/Chinese translation services are sought by government bodies and companies from China, Macao, Portugal, Portuguese-speaking African Countries and Timor. 
these two worlds have multiplied - it is expected that, in the future, economic relations between these countries will be intensified and, hence, the demand for translators will increase.

Macao has been and goes on being a breeding ground for the provision of translation work, and this market was substantially extended after 2003, with the policy establishing Macao as a Platform between these countries and the Mainland.

This global translation market requires a diagnosis of Macao's reality, and to define the physical dimension of the translation market for locally trained professionals, we need to inquire them, as well as the recent graduates about their professional interests and their willingness to accept the employment offers. Thus, it seems necessary to distinguish between the potential market and the real labor market, being the first, in a globalized and highly connected world, all employment opportunities available anywhere, in any field or sector, while the second is more restricted and includes only the existing opportunities in the market(s) where the translators are searched for and they accept the job.

In a narrow sense, when referring to locally trained translators, further research is required in order to get answer for the following questions: WHEN, WHERE and WHO offers translation work, WHO seeks that work, and is it rewarding?

In the past, the training of translators was exclusively targeted for Macao's market, more precisely, public administration services and government agencies. The Chinese Affairs Bureau (Alves, 2003) was the translation center, assuming a centralization role and having the exclusive right to assess the interpretation/translation authenticity (Dec-Law No. 47/76 / M, art. 2 b), c), d), e), f) and g) and Statutory Instrument No. 1724); it also provided support to other government services. Gradually, it was registered a strong decentralization due to the initiative of some public departments in recruiting translators, on the one hand, and, on the other hand, resorting to "(...) allocate bilingual staff from other careers" (Alves, 2003: 75), to other positions for supporting translators, namely, as proofreaders and editors. 
Concerning the demand, Alves states that there has been a gradual and continuous increase in the number of translations, especially of official nature, and that “(...) almost all public services, public companies or public assets entities (...) have requested more often the intervention of interpreters-translators" (2003: 76).

The analysis of the workload in the Public Administration Translation Centre, between 1996 and 2001 ${ }^{11}$, illustrates the situation of the local labor market, where the demand ${ }^{12}$ for these professionals has been higher than the supply, creating an imbalance in the labor market translation of Portuguese/Chinese.

Aguiar states that there is "a need for translators and interpretation throughout the Government, (...). This need is not only expressed by the interpreters-translators themselves. Those in charge of public services also point the need for more professionals in the area of Portuguese/Chinese translation (...)" (2002: 58).

Nowadays, this "(...) environment of shortage of professionals both in the public sector and in the private sector" (Aguiar, 2002: 59) still exists, but, in our view, is linked essentially to the needs of the local market and how Macao candidates face their professional future. The situation is complex as there is still a lack of translators for the local market and a considerably increase of job opportunities for these professionals, especially due to the economic and political cooperation between China, Macao and the Portuguese Speaking Countries.

The major milestone, arising from the conclusion of the First ministerial meeting of the Forum for Trade and Economic Cooperation between China and Portuguese-speaking Countries, held in October 2003, consists of implementing the political policy

11 The period before the handover and subsequent shows a significant increase in the demand for translation, from both official and private sectors, resulting in shortage of translators.

${ }^{12}$ Although the number of requests has been declining, the volume of translated pages is almost the same and there was no significant decrease, which is, in our opinion, a positive situation, considering that the various public departments were having, gradually, their own translators. 
of making Macao a Platform for higher education on languages and translation, namely, in both official languages. Macao's mission is to serve as a facilitator and promoter of economic and cultural cooperation between China and the Portuguese-speaking world. Under this policy, it was established an Action Plan for Economic and Trade Cooperation, it was created the Forum for Economic and Trade Cooperation between China and Portuguese-speaking Countries with a Permanent Secretariat (based in Macao), aiming to boost the commercial and cultural relations between these countries. The activity was focused on participation in products Fairs and Exhibitions (eg Macao International Fair, International Fair for Investment and Xiamen Trade), in carrying out market research for business investments and business seminars including presentation sessions regarding trade and investment environment, the training of human resources, among others, which has increased the volume of information and communication in both languages ${ }^{13}$.

This idea is reinforced by the President of the Macao Polytechnic Institute, stating that it appears that "(...) an increase in the PRC contacts with Portuguese-speaking countries increases the need to train bilingual personnel who can ensure that connection (...)" (Drago, 2003: 52).

At first glance, we are led to think that enacting this policy would expand the translation labor market; however, opinions are divided between those who consider that Macao has a vital role in the Forum's activities and those who think that the role of Macao is no more than political will, because, actually, China has a direct contact with those countries and does not have to resort to Macao so, the impact of the Forum in the translation market, would be null or inexpressive.

13 For $\mathrm{Yu}$ “(...) the exchange between China and the Portuguese-speaking Countries, the Portuguese and Chinese Languages should naturally be the instruments that both parties use" (2006: 11) and, in fact, there has been one "(...) improvement in use the bilingualism in Chinese and Portuguese in bilateral activities" (Yu, ibidem). 
It is our opinion that it is a very complex situation, not only related to economic policy decisions, but also due to higher offer in China market as the number of bilingual Chinese (PortugueseChinese) is growing year by year. Indeed, there is a great number of mainlanders students in Macao, Portugal and Brazil learning Portuguese and Mainland China Universities have invested in disseminating and teaching of Portuguese Language. Progressively, Mainland China is fostering Chinese professionals who know Portuguese as a second language, what, in our view, may reduce the demand, for translation services from Mainland China and Portuguese-speaking Countries; on the other hand, it facilitated the Mainland Chinese translators entry in the Macao translation market because, even if they are not allowed to live and work in Macao, they can work online for clients in any part of the world.

The command of the Portuguese language today is an asset and the opportunity to experience a world that embraces every continent, but also a valuable working tool that opens professional perspectives, especially for mainlander graduates. But, in spite of this positive scenario there are some constraints, as students from the Mainland have $100 \%$ employment guaranteed as translators, but Macao graduates "have easier opportunities to find jobs, but, mostly, those are not within the area of Translation, due to various reasons, basically the lack of professional experience" (Choi, Wa - Hoje Macao newspaper, 06/02/09).

Assuming that the potential employment opportunities in foreign markets would increase, it is relevant whether the graduates in translation are interested in competing in a global market.

Espadinha (2009) considers that it is a widespread opinion that "(...) those from Macao don't want to leave the territory, have little curiosity about the world", their objective is to work in Macao and they self-restrict their opportunities, because they aim to the Civil Service jobs, even if it means having to work in a different area. There are also a significant number of professionals who know the chances of working abroad and/or feel they lack skills to compete in an international market. 
For Ehrenberg and Smith there are several reasons that lead workers not to seek work outside their hometown: "[f]irst, information flows are imperfect, so workers may be unaware of the availability of jobs hundreds of miles away. Second, the direct money costs of such a move (...). Third, the psychological costs of moving long distances are substantial because friends and neighbors and community support systems must be given up" (2003:518).

Focusing on local market and the demand for translators, our objective was to identify the main job opportunities for graduates from Macao Polytechnic Institute. The results of the survey confirm, clearly, that the main local career opportunities have been, are and will continue to be, the Public Administration and Law area, having been witnessing an emergence of a market related to cultural relations and economic activities between China and Portuguese-speaking countries.

In the local market there is an "incongruence" as some graduates face difficulties in finding a job as a translator, especially in the Macao Public Administration, the first choice for most of them, and the employers also find difficult to recruit enough qualified professionals. Despite the need in the various government services, recruitment and selection in the Public Administration is governed by rules and the graduates hardly can be approved in the selection exams. Jose $\mathrm{Chu}$, points out one of the biggest problem: "[is] difficult to recruit staff due to lack of experience. Services cannot receive professionals with only basic training ${ }^{14}$ ".

From what has been said, the actual market for graduates of Macao in translation is restricted to Macao and almost exclusively to the Public Administration, so that we have a single local market governed by well-defined rules and procedures.

Reviewing what was stated at this point, we believe that the consequences of increased demand due to globalization movement were felt in Macao, as it was the demand due to policy "Macao as a Platform between China and the Portuguese-speaking Countries".

${ }^{14}$ Jornal Hoje Macau (newspaper) on 06/02/2009. 
In this latter case, we consider that those consequences were only slight ones, because it is a highly complex situation, with variables that affect its potential to increase, working conditions in Macao, "unwillingness" to go out of Macao, emergence of Mainland China professionals with strong appetite for foreign markets, including Macao, among others. Today, the market for translation, including Macao, has become more competitive and "appetizing", but Macao translators do not react quickly enough and do not adapt to the new reality, risking to become outdated and excluded.

Another relevant factor influencing the market is the translators' wages and the price of translation work. The career of interpreter/ translator in Macao public sector is attractive, with good work conditions, salary and benefits. In addition, the price paid by public and private clients for translation work was high, given the scarcity of translators. With the arrival of new translators in the market arena due to the increasing number of graduates from Macao, Mainland China and Portugal ${ }^{15}$ the situation is changing, as small companies and freelance translators practice lower prices in order to get selected and enter into market. There is an exception, as the Public Administration has strict rules for outsourcing, making it impossible for foreign translation companies or freelancers, even for those from Mainland to compete with local ones.

\section{Translation Labor market: translators point of view}

One of the questions of the survey aimed to identify the areas where, in their experience, there is more demand of translation in both official languages.

15 The Information and Communications Technologies allows translators to work for clients from anywhere in the world and Macao started using the services of mainland translators living in China. 
Table 1: Areas where there is a need for $\mathrm{T} / \mathrm{I} \mathrm{Ch} / \mathrm{Pt}$

\begin{tabular}{|l|l|l|}
\hline Areas & $\mathrm{N}$ & $\%$ \\
\hline Economy & 32 & $28,8 \%$ \\
\hline Finance & 30 & $27,0 \%$ \\
\hline Law & 101 & $\mathbf{9 1 , 0 \%}$ \\
\hline Public Administration & 65 & $\mathbf{5 8 , 6 \%}$ \\
\hline Tourism & 34 & $30,6 \%$ \\
\hline Gambling & 15 & $13,5 \%$ \\
\hline Consular Activities & 30 & $27,0 \%$ \\
\hline Telecommunications & 24 & $21,6 \%$ \\
\hline Literature & 36 & $32,4 \%$ \\
\hline Cultural events & 34 & $30,6 \%$ \\
\hline Other & 8 & $7,2 \%$ \\
\hline \multicolumn{1}{|c|}{ Total } & $* 409$ & \\
\hline $\begin{array}{l}\text { * Multiple answer question; the sum in } \\
\text { the percentage column does not add to } \\
\text { 100\%. }\end{array}$ & & \\
\hline
\end{tabular}

The Law area is where there is a heavier workload, as referred by $91 \%$ of the114 respondents. Although there is no specialization, this is the area with more employment opportunities. The Public Administration appears in second place as an employment opportunity, with $58.6 \%$ of choices. Literature $(32.4 \%)$, cultural events and services related to tourism $(30.6 \%)$ are still areas that can cater significant number of professionals. These values suggest that in Macao there is a market niche in the areas of Law and Public Administration and, although most locally trained translators work in these specific areas, there is still a need for more professionals.

In a second step, we intended to identify the areas where respondents have been requested to translate. 
Table 2: Areas where translation and/or interpretation has been made

\begin{tabular}{|l|l|l|}
\hline Working areas & $\mathrm{N}$ & $\%$ \\
\hline Economy & 17 & $17,0 \%$ \\
\hline Finance & 24 & $24,0 \%$ \\
\hline Law & 51 & $\mathbf{5 1 , 0 \%}$ \\
\hline Public Administration & 73 & $73,0 \%$ \\
\hline Tourism & 11 & $11,0 \%$ \\
\hline Gambling & 12 & $12,0 \%$ \\
\hline Consular activities & 7 & $7,0 \%$ \\
\hline Telecommunications & 7 & $7,0 \%$ \\
\hline Literature & 11 & $11,0 \%$ \\
\hline Cultural events & 15 & $15,0 \%$ \\
\hline Other & 21 & $21,0 \%$ \\
\hline Total & $* \mathbf{2 4 9}$ & \\
\hline $\begin{array}{l}* \text { Multiple answer question; the sum in the percentage column does } \\
\text { not add to 100\%. }\end{array}$ & \\
\hline
\end{tabular}

The total of answers reached 249, meaning that each of the respondents has chosen more than one area; in fact, the average number of areas for each translator is 2.2. The more significant areas are the Public Administration - $73 \%$ and the Law - 51\%, followed by Finance (24\%), Economy (17\%), Cultural events (15\%), Gambling (12\%), and services related to Tourism (11\%), Literature (11\%), Consular activities $(7 \%)$ and Telecommunications (7\%).

In addition to the areas we identified, the respondents could indicate other missing choices, thus resulting a wide range of areas; one of the respondents made a statement that summarizes the situation: "in Macao there are no translation specializations". Other areas mentioned are (from more to less frequent groups): 
engineering, construction, health, sports, accounting, security, media, environment, medicine, nursing, topography, cartography, road planning, land management, welfare work, among others.

More areas could be added, but the answers reveal Macao's reality, a very small market where the dimension of public services and companies does not allow the specialization of translators in one specific field, as they need to switch between multiple areas, swapping between interpretation and translation, in addition to translating from a foreign language into their mother tongue or vice versa. And this, happens all the time, in the same day, it's a regular situation accepted by everyone as something intrinsic to the reality of a local translator.

\section{Employment opportunities after graduation}

Most people attend higher education in order to acquire skills to enable them to perform a professional activity. Therefore, when making a decision to enroll in a particular program they ask: "After the graduation what am I going to do?"

Regarding our respondents, when entering into the translation course, most of them already have a stable professional activity in the public sector in other areas, and they need to make an important decision after they complete their studies. Now what? Moving to the translation market? The decision depends on the confidence they have in their own competences as translators and also on the opportunities to change without losing benefits and status.

Table 3: Career Opportunities

\begin{tabular}{|l|l|l|}
\hline Career Opportunities & $\mathrm{N}$ & $\%$ \\
\hline Macao Public Administration & 59 & $\mathbf{7 3 , 8 \%}$ \\
\hline Law & 18 & $22,5 \%$ \\
\hline Portuguese Speaking Countries & 7 & $8,8 \%$ \\
\hline
\end{tabular}




\begin{tabular}{|l|l|l|}
\hline Private Sector & 10 & $12,5 \%$ \\
\hline Few or none job opportunities as translators & 6 & $7,5 \%$ \\
\hline All areas & 5 & $6,3 \%$ \\
\hline Entities working with PRC & 1 & $1,3 \%$ \\
\hline Tourism & 6 & $7,5 \%$ \\
\hline Portuguese Language Teachers & 2 & $2,5 \%$ \\
\hline Trade Area: Import/Export & 4 & $5,0 \%$ \\
\hline $\begin{array}{l}\text { Forum China/ Portuguese Speaking Countries } \\
\text { (Macao) }\end{array}$ & 3 & $3,8 \%$ \\
\hline United Nations Organization & 1 & $1,3 \%$ \\
\hline $\begin{array}{l}\text { Translation/Interpretation Companies } \\
1 \\
1,3 \%\end{array}$ & \multicolumn{2}{|l|}{} \\
\hline China and/or Portugal & 2 & $2,5 \%$ \\
\hline Diplomatic area & 2 & $2,5 \%$ \\
\hline Security Forces & 1 & $1,3 \%$ \\
\hline Banking & 1 & $1,3 \%$ \\
\hline Gambling & 2 & $2,5 \%$ \\
\hline Total & $\mathbf{1 3 1}$ & \\
\hline $\begin{array}{l}* \\
\text { Multiple answer question; the sum in the }\end{array}$ & & \\
\hline
\end{tabular}

The data shows that the Public Administration sector is singled out as the main job opportunity for graduates (73.8\%); Law also appears as an important source of work $(22.5 \%)$. The private sector is reported by $12.5 \%$ of respondents, tourism by $7.5 \%$ and the import and export activity only by $5 \%$. Although the main economic activity in Macao is gambling, this is only mentioned by $2.5 \%$ of respondents. Only $1.3 \%$ indicated the translation companies, organizations working with Mainland China, Security Forces and United Nations each as job opportunities. It is interesting to note that Portuguese-speaking Countries (8.8\%) and Forum 
China/Portuguese-speaking Countries, Macao (3.8\%) started to emerge as a professional opportunity for translators. Although it is not directly related to the field of our study some respondents pointed out that the degree allows the access to a career as teacher of Portuguese. From our experience we can affirm that Macao translators do not envision teaching as a career opportunity, but the graduates in translation from Portugal and China are working as teachers, mainly as Portuguese teachers, in Mainland China.

Some of the respondents have a negative attitude considering that there are few or no jobs $(7.5 \%)$ but another group maintains a positive attitude and state that all areas need translation services (6.3\%).

In short, according to the answers, we can reaffirm that there is a lack of translation professionals in Macao and a huge demand for translation in various areas, specially, in public administration and law.

\section{Employment as a translator/interpreter abroad}

Given the small dimension of Macao and the relative recentness of higher education, some programs are not available to students and for some fields of study, students have to go abroad to continue their studies. As a teacher in higher education, we notice that some students choose one program because they don't have conditions or don't want to live abroad. This assumption was confirmed by the results as some of them point out that they have chosen translation because they "do not want to leave Macao". Similar answers appear in other question regarding the idea of working abroad, where only $23 \%$ responds affirmatively ${ }^{16}$.

${ }_{16}$ These want to work abroad to widen horizons, gain experience, meet other cultures; one says that it was only "Dreaming". 
Table 4: Willingness to wrk outside Macao

\begin{tabular}{|c|c|c|}
\hline Work outside Macao & $\mathrm{N}$ & $\%$ \\
\hline Yes & 26 & 23,0 \\
\hline No & 87 & 77,0 \\
\hline Total & 113 & 100,0 \\
\hline
\end{tabular}

Most of respondents (77\%) don't want to work abroad because the Public Administration still needs translators and it offers a job for life and a career with a high salary and good benefits.

Why they have so little interest to work as translators abroad?

The answers allowed us to identify another sort of reasons for not wanting to leave Macao, which we had not considered in the survey. Those reasons, frequently expressed in responses to different questions, are related to the lack of confidence in their own knowledge and the assumption that outside Macao they would face many obstacles, due to insufficient training for competing in the international market.

In addition to the above mentioned reasons, they are not seeking employment abroad because: (1) family reasons - 33.3\%; (2) having already a good professional situation (including salary) in Macao, and being adapted to the working environment $-20.5 \%$; (3) considering that it is a difficult profession, that is, is a hard and tiring work - $16.7 \%$; (4) the labor market outside Macao and Portuguese Speaking Countries is very low - 9.3\% . It is important to emphasize that some respondents consider that they are not prepared to enter this profession abroad, as they don't master the working language and are not prepared to face the challenges and the competition in the foreign translation market. 


\section{Entering the Labor Market}

For most individuals after graduation from higher education, the first step is finding a job in their area of studies or in a compatible ${ }^{17}$ one. Graduates of the translation program were not looking for their first job, as, among respondents, only $17.5 \%$ did not have a job and only $0.9 \%$ reported being unemployed when they enter into the translation course.

Our question (After getting the degree, is it easy to find a job as a translator and/or interpreter?) had the objective of identifying, in the labor market, whether there is a large demand for translators and if there are any obstacles to enter into the translator community.

Excluding the $7.9 \%$ that did not respond and for the majority $(65.7 \%)$, the entry into the labor market was relatively easy, while $34 \%$ indicated that they had difficulties in finding employment in the translation area.

There are some cases of graduates in Law who enter into the translation program with the objective of improving their knowledge of Portuguese, but without any intention to pursue the translation career, as in Macao they can work in the law area ${ }^{18}$ and get excellent income and good social status.

Joining the Public Administration is the biggest difficulty. $19.4 \%$ of respondents referred the lack of job openings, and $9.7 \%$ mentioned the small number of vacancies, as the main problems that hinder the entry into the labor market.

Three other obstacles (6.5\% each) are identified, namely, difficulty in succeeding in the selection tests for Public

\footnotetext{
17 The results of the study conducted by the Gabinete Coordenador dos Serviços Sociais Sheng Kung Hui Macao, released in 2105, reveals that young people in Macao want to get a degree but, at the moment to seek employment, the priority is the higher payment and benefits, shifting easily from job to job if this means higher salary and social status.

${ }^{18}$ There are lots of opportunities for Law graduates, lack of professionals and its social status is higher than the translator's status. In Macao, it is more frequent a translator moving to the law area than the opposite.
} 
Administration and lack of experience Finally, there are several other answers, such as: (1) lack of interest in becoming a translator - $12.9 \%$; (2) no internship, lack of practice opportunities - 9.7\%; (3) lack of job attractiveness: it occurs when the graduates already have a relatively stable job with equal or greater status, for example, a management position - 9.6\%; (4) tried but failed or succeeded only one year after finishing the course - 6.4\%; (5) lacking confidence in their skills and courage $-6.4 \%$; (6) lack of market opportunities, i.e., few jobs as a translator and/or interpreter $6.4 \%$; (7) Age - some graduates have finished their degree over 45, which made it difficult to enter the translation labor market - $3.2 \%$; (8) Complexity of Portuguese Language for Chinese mother tongue students - 3.2\%; and (9) Increased competition - 3.2\%. There is also a reference to the difficulty in being a good translator as one of the obstacles for entering into the labor market.

Given that $71.9 \%$ of students were already civil servants, when starting the course, it is not surprising that $93.2 \%$ of respondents say that they intend to develop their professional activity in the Macao public services, after finishing their studies.

Note that, although the relations between China and the Portuguese-speaking world policy was implemented recently (since 2003), it already has impacted the translation market in Macao and the graduates integrate official institutions $(1.4 \%$ performing translator functions in Forum for Economic and Trade Cooperation between China and Portuguese-speaking countries in Macao), as well as in the private entities $(1.4 \%$ are translators in the business area between China and the group of Portuguese-speaking countries).

We found that, despite the need for law related translation work in private institutions, private lawyers and notaries' offices, only $1.4 \%$ of translation professionals are working in the private sector what illustrates the success of government training policies to meet their own needs and its ability to attract these professionals.

The results of the survey targeted to law firms also confirm this assumption; all firms referred that they need translators, but they are not able to recruit them on the Macao market. 


\section{The future of translation Portuguese/Chinese translation labor market}

Short-term projections for a period of five years are very positive, with $69.6 \%$ of respondents stating that there will be an increase in demand in the Portuguese/Chinese translation labor market; $12.5 \%$ predict stagnation, $17 \%$ expect a decrease and one respondent is more precise, stating that we will witness an increase in the area of law, but a decrease in all other areas.

The growing cooperation between China, Macao and the Portuguese Speaking Countries leads us to reflect on the role of Macao as a Platform and consequently its impact on the translation labor market. But, what do the translators think about this issue? How has this policy and its implementation impacted the translation market? The majority of respondents $(76.9 \%)$ felt that this new factor had impacted the market and $23.1 \%$ believe that it did not affect the demand for translation work.

Among those who responded affirmatively, $60.3 \%$ consider that this policy led to an increase in the demand, especially in the private sector, due to a rise in the number of events requiring translation services $(14.7 \%)$ and to the need to seek information related to the various Portuguese-speaking countries (4.4\%).

This duality of understanding is expressed in the comments sections of the survey: (1) the policy Macao as a Platform between Portuguese speaking countries and China has been felt in several ways in the translation market; (2) the increasing interest of Chinese people in studying Portuguese as a second language, along with the interest in learning Mandarin from Portuguese-speaking people will allow people to communicate without having to resort to the services of translators/interpreters for official contacts. On the other hand, this policy and the consequent increase in demand is visible in the newspapers displaying job offers advertisements seeking Portuguese/ Chinese translators and interpreters for private enterprises in China, Macao, Portugal, Brazil, Angola, among others - stressing the need for the training of translators. Moreover, a large number of political 
speeches reinforce the idea that Macao has an important role to play as a center for Portuguese language and translation learning, serving China and the Portuguese speaking countries.

\section{Conclusion}

The results lead us to state that in Macao there is a lack of translators. Simultaneously, there are cases of non-inclusion in the translation labor market because, on the one hand, employers have expectations hardly met by the candidates, and on the other hand, graduates are selective and try to avoid employment outside the public administration, as the private sector can't offer such good conditions and benefits. Moreover, they do not envision the possibility of working abroad, looking for work only in the domestic market.

All the answers lead us to conclude that there is a huge challenge period for Macao translators because, whereas the market is expanding, there is an increased competition, both internally and externally, as the commercial exchange between China and the Portuguese Speaking Countries is growing, leading to a higher demand. However, it is important to note that Macao's higher education institutions are enrolling Mainland China students and nowadays, those institutions no longer face the lack of students for translation or languages programs, especially in Portuguese and Chinese translation. Moreover, China's universities are, gradually, offering more degrees in Portuguese language. Chinese graduates are eager to look for translation jobs and mentally prepared to perform in the global market. For Macao's translators this is a new reality, as they never faced competition.

To face all those challenges, Curricula design must reflect the translator's needs: acquire the skills to become, simultaneously, translators and interpreters, to deal with a wide range of subjects and also translating and interpreting in both directions, Portuguese into Chinese and vise versa. It is important to connect students, 
professional translators, public and private sector market agents, in order to identify the needs and expectations, to identify the real situation of the translator community, for designing the relevant and appropriate curricula.

In our opinion it's urgent to make some changes in the curricula in order to give students opportunities to practice in a real work environment: internships in public and private entities; the education institutions must provide real work to students, namely, creating translation centers where students, supervised by teachers, can do translation work for real clients and get paid for it.

The path of cooperation between local and international universities must also be deepen as the programs that already exist have shown positive results, but it is important to reinforce- that professionals and market agents have a very important role to play and the decision makers must listen to them.

There is a potential development that points to a future of higher demand for Portuguese/Chinese languages translators and Macao can become a translators training center. Higher education institutions, such us the Polytechnic must be proactive, anticipate the needs that will arise and give an appropriate response, facing the present and anticipating the future.

\section{References}

AGUIAR, M. T. S. (2002). Tradução e Interpretação em Macau. Em: IPM. Workshop de Tradução e Interpretação no Novo Milénio. Macau: IPM, 31-62.

ALVES, J. M. (2003). A Administração Portuguesa de Macau e a Língua Chinesa: Relatório da Comissão para a Implementação da Língua Chinesa - Documentação Complementar - 1985-1986. Macau: Coord. e Edição de João C. Reis. 
DRAGO, J. (2003, Agosto). Os novos desígnios do Ensino Superior. Revista Macau, III Series, 15, 52-70.

DUFF, A. (1989). Translation. Oxford: Oxford University Press.

EHRENBERG, R. G. e SMITH, R. S. (2008). Modern Labor Economics: Theory and Policy (10th Edition). Toronto: Addison Wesley.

LAJES, A. (06/02/09). Nada como Antigamente: Politécnico forma mais de 100 tradutores por ano. Jornal Hoje Macau. [Online], [Accessed on 07-02-2009]. Available at: www.hojemacau.com/news.phtml $? \mathrm{id}=32455 \&$ today $=06022009$.

MAR, D. e NEVES, P. (2009, 16 de Março). Interview with Maria Antónia Espadinha: Interesse pela Língua Portuguesa tem crescido. Jornal Tribuna de Macau. [Online], [Accessed on 17-03-2009]. Available at: http://www.jtm.com. mo/view.asp?dT $=309603001$.

YU, H. (2006). O Papel da tradução chinês/português na Cooperação Económica e Comercial entre a China e os Países de Língua Portuguesa. Boletim Trimestral no 3. Macau: Fórum para a Cooperação Económica e Comercial entre a China e os Países de Língua Portuguesa, 11-13.

Recebido em: 28/12/2015

Aceito em: 24/02/2016 Publicado em maio de 2016 